\title{
Icotinib antagonizes ABCG2-mediated multidrug resistance, but not the pemetrexed resistance mediated by thymidylate synthase and ABCG2
}

\author{
De-Shen Wang ${ }^{1,2, *}$, Atish Patel ${ }^{2,}{ }^{*}$, Suneet Shukla ${ }^{3}$, Yun-Kai Zhang ${ }^{2}$, Yi-Jun Wang ${ }^{2}$, \\ Rishil J. Kathawala ${ }^{2}$, Robert W. Robey ${ }^{4}$, Li Zhang ${ }^{1}$, Dong-Hua Yang5, Tanaji T. \\ Talele $^{2}$, Susan E. Bates ${ }^{4}$, Suresh V. Ambudkar ${ }^{3}$, Rui-Hua Xu ${ }^{1 *}$ and Zhe-Sheng Chen ${ }^{2}$ \\ 1. Department of Medical Oncology, Sun Yat-sen University Cancer Center, State Key Laboratory of Oncology in South China, \\ Collaborative Innovation Center for Cancer Medicine, China \\ 2. Department of Pharmaceutical Sciences, College of Pharmacy and Health Sciences, St. John's University, Queens, New \\ York, USA \\ 3. Laboratory of Cell Biology, Center for Cancer Research, National Cancer Institute, NIH, Bethesda, Maryland, USA \\ 4. Medical Oncology Branch, Center for Cancer Research, National Cancer Institute, NIH, Bethesda, Maryland, USA \\ 5. Biosample Repository Facility, Fox Chase Cancer Center, Philadelphia, PA 19111, USA \\ "These authors contributed equally to this work \\ Correspondence to: Zhe-Sheng Chen, email: chenz@stjohns.edu
}

Rui-Hua Xu, email: xurh@sysucc.org.cn

Keywords: Icotinib; $A B C G 2 ;$ Reversal of drug resistance; thymidylate synthase; Lung cancer

Received: April 11, $2014 \quad$ Accepted: June 12, $2014 \quad$ Published: June 13, 2014

This is an open-access article distributed under the terms of the Creative Commons Attribution License, which permits unrestricted use, distribution, and reproduction in any medium, provided the original author and source are credited.

\section{ABSTRACT}

ABCG2 is a potential biomarker causing multidrug resistance (MDR) in NonSmall Cell Lung Cancer (NSCLC). We conducted this study to investigate whether Icotinib, a small-molecule inhibitor of EGFR tyrosine kinase, could interact with ABCG2 transporter in NSCLC. Our results showed that Icotinib reversed ABCG2-mediated MDR by antagonizing the drug efflux function of ABCG2. Icotinib stimulated the ATPase activity in a concentration-dependent manner and inhibited the photolabeling of ABCG2 with [ ${ }^{125}$ I]-Iodoarylazidoprazosin, demonstrating that it interacts at the drugbinding pocket. Homology modeling predicted the binding conformation of Icotinib at Asn629 centroid-based grid of ABCG2. However, Icotinib at reversal concentration did not affect the expression levels of AKT and ABCG2. Furthermore, a combination of Icotinib and topotecan exhibited significant synergistic anticancer activity against NCI-H460/MX20 tumor xenografts. However, the inhibition of transport activity of ABCG2 was insufficient to overcome pemetrexed resistance in NCI-H460/MX20 cells, which was due to the co-upregulated thymidylate synthase (TS) and ABCG2 expression. This is the first report to show that the up-regulation of TS in ABCG2overexpressing cell line NCI-H460/MX20 may play a role of resistance to pemetrexate. Our findings suggested different possible strategies of overcoming the resistance of topotecan and pemetrexed in the NSCLC patients.

\section{INTRODUCTION}

Multidrug resistance (MDR) in cancer is a major impediment for successful chemotherapy [1]. Currently, 48 different $\mathrm{ABC}$ transporters have been identified in the human genome and classified into 7 subfamilies (A-
$\mathrm{G})$ based on similarities in sequence as well as structural organization [2]. ABCG2 transporter is a $72 \mathrm{kDa}$ half transporter which was identified from a doxorubicinselected MCF-7 human breast cancer cell line [3], human placenta [4], and a colon cancer cell line (S1-M1-80) [5]. Drugs transported by ABCG2 include a variety of anticancer agents such as mitoxantrone, topoisomerase I 
Table 1: Icotinib reverse the ABCG2-mediated drug resistance in drug selected resistant NSCLC cells.

\begin{tabular}{|c|c|c|c|c|c|c|}
\hline & \multicolumn{6}{|c|}{$\mathrm{IC}_{50} \pm \mathrm{SD}^{\mathrm{a}}(\mu \mathrm{M})$} \\
\hline Compounds & A549 & $(\mathrm{RF})^{\mathrm{b}}$ & NCI-H460 & $(\mathrm{RF})^{\mathrm{b}}$ & NCI-H460/MX20 & $(\mathrm{RF})^{\mathrm{b}}$ \\
\hline Mitoxantrone $(\mu \mathrm{M})$ & $0.2853 \pm 0.0214$ & 1 & $0.0668 \pm 0.0033$ & 1.0 & $5.0837 \pm 0.7542$ & 76.0 \\
\hline+ Icotinib $1.0 \mu \mathrm{M}$ & $0.2269 \pm 0.0193$ & 0.8 & $0.0354 \pm 0.0028^{*}$ & 0.5 & $1.9336 \pm 0.1121^{*}$ & 28.9 \\
\hline+ Icotinib $5.0 \mu \mathrm{M}$ & $0.1695 \pm 0.0102 *$ & 0.6 & $0.0314 \pm 0.0022 *$ & 0.5 & $0.3559 \pm 0.0249 *$ & 5.3 \\
\hline+ FTC $5.0 \mu \mathrm{M}$ & $0.1858 \pm 0.0167^{*}$ & 0.7 & $0.0300 \pm 0.0023 *$ & 0.4 & $0.3316 \pm 0.0265^{*}$ & 5.0 \\
\hline SN-38 $(\mu \mathrm{M})$ & $0.6251 \pm 0.0313$ & 1.0 & $0.0707 \pm 0.0035$ & 1.0 & $8.1222 \pm 1.006$ & 114.9 \\
\hline+ Icotinib $1.0 \mu \mathrm{M}$ & $0.2482 \pm 0.0199 *$ & 0.4 & $0.0202 \pm 0.0016^{*}$ & 0.3 & $2.6770 \pm 0.1553^{*}$ & 37.8 \\
\hline+ Icotinib $5.0 \mu \mathrm{M}$ & $0.1717 \pm 0.0120^{*}$ & 0.3 & $0.0150 \pm 0.0011 *$ & 0.2 & $0.3271 \pm 0.0229 *$ & 4.6 \\
\hline+ FTC $5.0 \mu \mathrm{M}$ & $0.1752 \pm 0.0131^{*}$ & 0.3 & $0.0166 \pm 0.0012 *$ & 0.2 & $0.3126 \pm 0.0250^{*}$ & 4.4 \\
\hline Topotecan $(\mu \mathrm{M})$ & $1.4551 \pm 0.1237$ & 1.0 & $0.0490 \pm 0.0042$ & 1.0 & $4.8721 \pm 0.4141$ & 99.4 \\
\hline+ Icotinib $1.0 \mu \mathrm{M}$ & $0.9458 \pm 0.0851 *$ & 0.7 & $0.0226 \pm 0.0020^{*}$ & 0.5 & $0.1261 \pm 0.0113^{*}$ & 2.6 \\
\hline+ Icotinib $5.0 \mu \mathrm{M}$ & $0.9313 \pm 0.0931^{*}$ & 0.6 & $0.0196 \pm 0.0019 *$ & 0.4 & $0.0598 \pm 0.0060^{*}$ & 1.2 \\
\hline+ FTC $5.0 \mu \mathrm{M}$ & $1.0186 \pm 0.0866^{*}$ & 0.7 & $0.0194 \pm 0.0016^{*}$ & 0.4 & $0.0639 \pm 0.0054^{*}$ & 1.3 \\
\hline Cisplatin $(\mu \mathrm{M})$ & $2.7677 \pm 0.2214$ & 1.0 & $1.2692 \pm 0.1015$ & 1.0 & $1.3200 \pm 0.1056$ & 1.0 \\
\hline+ Icotinib $5.0 \mu \mathrm{M}$ & $2.9831 \pm 0.1492$ & 1.1 & $1.2727 \pm 0.0636$ & 1.0 & $1.2012 \pm 0.0841$ & 0.9 \\
\hline+ FTC $5.0 \mu \mathrm{M}$ & $3.2343 \pm 0.2264$ & 1.2 & $1.2017 \pm 0.0841$ & 0.9 & $1.2540 \pm 0.0627$ & 1.0 \\
\hline
\end{tabular}

a. $\mathrm{IC}_{50}$ values are represented the mean \pm standard deviation (SD).

b. Resistance fold (RF) was calculated by the $\mathrm{IC}_{50}$ values for different substrates, and cisplatin of NCI-H460/MX20 cells, divided by the $\mathrm{IC}_{50}$ values for the respective control without the reversing agents, or the resistant cell lines in the presence or absence of Icotinib or FTC, divided by the $\mathrm{IC}_{50}$ values for different substrates, and cisplatin of respective control without the reversing agents.

*. $\mathrm{P}<0.05$, versus the control group

inhibitors, anthracyclines, indolocarbazole, flavopiridol, antifolates and fluorescent dyes like Hoechst 33342 [6].

Recently, ABCG2 has been recognized as a molecular marker for the side population (SP) cells [7]. As for human Non-Small Cell Lung Cancer (NSCLC) cell lines, the presence of a Hoechst dye 33342 extruding in SP cells, which accounted for $0.03-6.1 \%$ of the tumor cells [8], have shown elevated expression of ABCG2, increased tumorigenicity in mice, and resistance to various chemotherapeutic agents [9]. Moreover, Yoh K et al. [10] found that positive immunostaining for ABCG2 appears to be a predictor of shorter survival in patients with advanced NSCLC. Recently, a phase III study demonstrated that pemetrexed/cisplatin was a standard regimen for firstline treatment of advanced non-squamous NSCLC [11]. However, some studies reported that ABCG2 also confer pemetrexed resistance $[12,13]$, which implied that blocking ABCG2-mediated active efflux function might substantially contribute to increased response and prolonged survival rates in patients with NSCLC [14].

Icotinib (BPI-2009H) is a specific small-molecule inhibitor of epidermal growth factor receptor (EGFR) tyrosine kinase, which has shown clinical anticancer activity in patients with advanced NSCLC [15]. However, there are still no biomarkers that reproducibly predicted the benefit of EGFR inhibitors in EGFR wild-type NSCLC patients, although they only produced a modest benefit in these patients [16]. In recent years, Gefitinib (ZD1839) and
Erlotinib (OSI-774) have been shown to reverse ABCG2mediated MDR $[17,18]$. It is conceivable that Icotinib might also inhibit the functions of $\mathrm{ABC}$ transporters by binding to the drug-binding domain. Therefore, we conducted this study to determine whether Icotinib could enhance the chemosensitivity of conventional anticancer drugs through interaction with ABCG2-mediated drug resistance in MDR NSCLC. We hypothesized that Icotinib might enhance the chemosensitivity of topotecan and pemetrexed in NSCLC.

\section{RESULTS}

\section{Effect of Icotinib induced reversal MDR in various MDR cells}

Firstly, we detected the ABCG2 expressing levels in the cells used in this study. Low levels of ABCG2 were intrinsically expressed in lung cancer cell lines NCI-H460 and A549 (Fig. 1B). However, NCI-H460/MX20, ABCG2482-R2, ABCG2-482-G2, and ABCG2-482-T7 cell lines showed much higher levels of ABCG2 expression (Fig. $1 \mathrm{~B}$ and $1 \mathrm{C})$, whereas the expression level of ABCG2 in the parental HEK293/pcDNA3.1 cell was undetectable (Fig. 1C). Secondly, we examined the reversal effect of Icotinib in ABCG2-mediated MDR cell lines (Table 1 
Table 2: The reversal efficacy of Icotinib in ABCG2-mediated drug resistance in ABCG2-transfected cell lines.

\begin{tabular}{|c|c|c|c|c|c|c|c|c|}
\hline & $\mathrm{IC}_{50} \pm \mathrm{SD}^{\mathrm{a}}(\mu \mathrm{N}$ & & & & & & & \\
\hline Compounds & $\begin{array}{l}\text { HEK293/ } \\
\text { pcDNA3.1 }\end{array}$ & $(\mathrm{RF})^{\mathrm{b}}$ & $\begin{array}{l}\text { ABCG2- } \\
482-R 2\end{array}$ & $(\mathrm{RF})^{\mathrm{b}}$ & $\begin{array}{l}\text { ABCG2- } \\
482-G 2\end{array}$ & $(\mathrm{RF})^{\mathrm{b}}$ & $\begin{array}{l}\text { ABCG2- } \\
482-\mathrm{T} 7\end{array}$ & $(\mathrm{RF})^{\mathrm{b}}$ \\
\hline Mitoxantrone $(\mu \mathrm{M})$ & $\begin{array}{ll}0.0557 & \pm \\
0.0028 & \end{array}$ & 1.0 & $0.5754 \pm 0.0460$ & 10.3 & $\begin{array}{ll}1.7045 & \pm \\
0.1364 & \end{array}$ & 30.6 & $\begin{array}{ll}1.1045 & \pm \\
0.0884 & \end{array}$ & 19.8 \\
\hline+ Icotinib $1.0 \mu \mathrm{M}$ & $\begin{array}{l}0.0533 \\
0.0037 \\
\end{array}$ & 1.0 & $\begin{array}{ll}0.3438 & \pm \\
0.0309 * & \end{array}$ & 6.2 & $\begin{array}{ll}0.7934 & \pm \\
0.0714 * & \end{array}$ & 14.3 & $\begin{array}{ll}0.5524 & \pm \\
0.0497 * & \\
\end{array}$ & 9.9 \\
\hline+ Icotinib $5.0 \mu \mathrm{M}$ & $\begin{array}{l}0.0503 \\
0.0040\end{array}$ & 0.9 & $\begin{array}{ll}0.0537 & \pm \\
0.0027 * & \end{array}$ & 1.0 & $\begin{array}{ll}0.0701 & \pm \\
0.0035^{*} & \end{array}$ & 1.3 & $\begin{array}{ll}0.0687 & \pm \\
0.0034^{*} & \end{array}$ & 1.2 \\
\hline+ FTC $5.0 \mu \mathrm{M}$ & $\begin{array}{l}0.0491 \\
0.0022\end{array}$ & 0.9 & \begin{tabular}{ll|}
0.0564 & \pm \\
$0.0023 *$ & \\
\end{tabular} & 1.0 & \begin{tabular}{ll|}
0.0645 & \pm \\
$0.0026^{*}$ &
\end{tabular} & 1.2 & \begin{tabular}{ll|}
0.0632 & \pm \\
$0.0025^{*}$ &
\end{tabular} & 1.1 \\
\hline SN-38 $(\mu \mathrm{M})$ & $\begin{array}{l}0.0070 \\
0.00035\end{array}$ & 1.0 & $0.1885 \pm 0.0151$ & 27.1 & $\begin{array}{l}0.2494 \\
0.0200\end{array}$ & 35.8 & $\begin{array}{l}0.2095 \\
0.0168\end{array}$ & 30.1 \\
\hline+ Icotinib $1.0 \mu \mathrm{M}$ & $\begin{array}{l}0.0067 \\
0.0005\end{array}$ & 1.0 & $\begin{array}{l}0.0612 \pm \\
0.0055^{*}\end{array}$ & 8.8 & $\begin{array}{l}0.0811 \\
0.0073 *\end{array}$ & 11.7 & $\begin{array}{ll}0.0750 & \pm \\
0.0068 * & \end{array}$ & 10.8 \\
\hline+ Icotinib $5.0 \mu \mathrm{M}$ & $\begin{array}{l}0.0063 \\
0.0005 \\
\end{array}$ & 0.9 & $\begin{array}{ll}0.0087 & \pm \\
0.0004 * & \end{array}$ & 1.2 & $\begin{array}{l}0.0080 \\
0.0004 *\end{array}$ & 1.2 & $\begin{array}{ll}0.0077 & \pm \\
0.0005^{*} & \end{array}$ & 1.1 \\
\hline+ FTC $5.0 \mu \mathrm{M}$ & $\begin{array}{l}0.0061 \\
0.0003\end{array}$ & 0.9 & $\begin{array}{ll}0.0075 & \pm \\
0.0003 * & \end{array}$ & 1.1 & $\begin{array}{l}0.0078 \\
0.0003 *\end{array}$ & 1.1 & \begin{tabular}{ll|}
0.0078 & \pm \\
$0.0003 *$ &
\end{tabular} & 1.1 \\
\hline Cisplatin $(\mu \mathrm{M})$ & $\begin{array}{l}1.6700 \\
0.0835\end{array}$ & 1.0 & $1.7045 \pm 0.1364$ & 1.0 & $\begin{array}{l}1.6045 \\
0.1284\end{array}$ & 1.0 & $\begin{array}{l}1.6704 \\
0.1336\end{array}$ & 1.0 \\
\hline+ Icotinib $5.0 \mu \mathrm{M}$ & $\begin{array}{l}1.5980 \\
0.1119\end{array}$ & 1.0 & $1.6662 \pm 0.1500$ & 1.0 & $\begin{array}{l}1.5524 \\
0.1397\end{array}$ & 0.9 & $\begin{array}{l}1.5500 \\
0.0775\end{array}$ & 0.9 \\
\hline+ FTC $5.0 \mu \mathrm{M}$ & $\begin{array}{l}1.5098 \\
0.1208\end{array}$ & 0.9 & $1.5801 \pm 0.0790$ & 0.9 & $\begin{array}{l}1.6873 \\
0.0844\end{array}$ & 1.0 & $\begin{array}{l}1.5400 \\
0.1001\end{array}$ & 0.9 \\
\hline
\end{tabular}

a. $\mathrm{IC}_{50}$ values are represented the mean \pm standard deviation $(\mathrm{SD})$.

b. Resistance fold (RF) was calculated by the $\mathrm{IC}_{50}$ values for different substrates, and cisplatin of resistant cell lines, divided by the $\mathrm{IC}_{50}$ values for the respective control without the reversing agents, or the resistant cell lines in the presence or absence of Icotinib or FTC, divided by the IC50 values for different substrates, and cisplatin of respective control without the reversing agents.

*. $\mathrm{P}<0.05$, versus the control group.

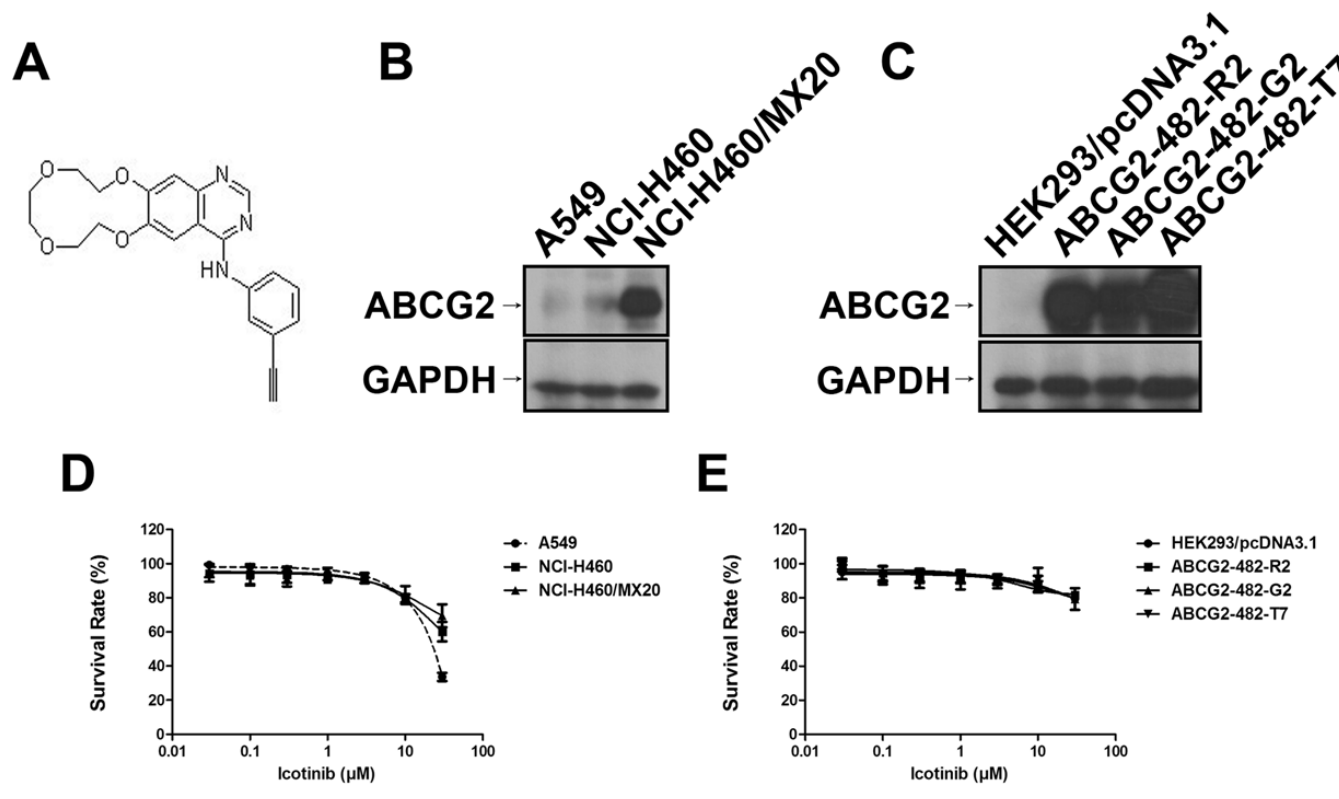

Fig. 1: Chemical structure of Icotinib (A), Western blotting to detect ABCG2-expression in NCI-H460, A549 cells and in ABCG2overexpressing NCI-H460/MX20 cell line (B) and transfected ABCG2-482-R2, ABCG2-482-G2, and ABCG2-482-T7 cell lines (C). Fig. 1 (D) and (E) represent the concentration-response curves of the cell lines treated with Icotinib alone. 
and Table 2). In order to avoid the cytotoxicity of Icotinib alone in the reversal experiments, the concentrations of Icotinib we used were 1.0 and $5.0 \mu \mathrm{M}$, at which about $85 \%$ of cells were viable. As shown in Table 1, NCI-H460/ MX20 cells possessed high resistance to the MX, SN-38 and topotecan that are substrates of $\mathrm{ABCG} 2$, compared with the NCI-H460 and A549 cells. Similarly, the ABCG2 transfected cell lines ABCG2-482-R2, ABCG2482-G2 and ABCG2-482-T7 also possessed resistance to mitoxantrone (MX), SN-38 and topotecan compared with HEK293/pcDNA3.1 cells (Table 2). However, Icotinib at $5.0 \mu \mathrm{M}$ significantly reversed the resistance of $\mathrm{MX}$, SN-38 and topotecan in both drug selected derivative and transfected ABCG2-overexpressing cells, as well as the intrinsically ABCG2 expressed A549 and NCI-H460 cells, and its reversal efficacy was comparable to the specific ABCG2 inhibitor Fumitremorgin C (FTC) (5.0 $\mu \mathrm{M})$. However, the reversal efficacy by Icotinib was not seen in HEK293/pcDNA3.1 cells. Meanwhile, there was no significant difference in the $\mathrm{IC}_{50}$ values for cisplatin, a non-substrate of ABCG2, with or without the combination of Icotinib in all tested cell lines (Table 1 and Table 2).

A
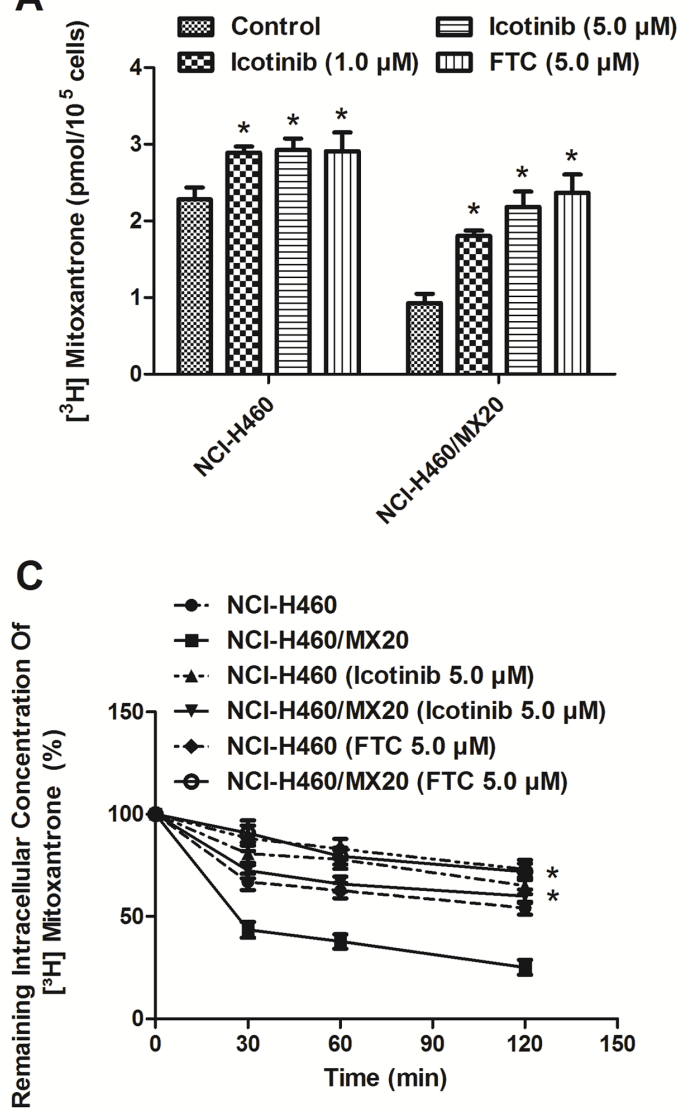

In order to determine the reversal specificity by Icotinib, we examined the reversal effect in ABCB1and ABCC10-mediated MDR cell lines. As shown in Supplementary Table S, Icotinib at $5.0 \mu \mathrm{M}$ did not reverse $\mathrm{ABCB} 1-$ and $\mathrm{ABCC} 10-$ mediated drug resistance in $\mathrm{HEK} / \mathrm{ABCB} 1$ and $\mathrm{HEK} / \mathrm{ABCC} 10$ cell lines. Our results suggested that Icotinib probably reverse ABCG2-mediated drug resistance selectively.

\section{Icotinib increased intracellular accumulation of $\left[{ }^{3} \mathrm{H}\right]-\mathrm{MX}$ and inhibited the efflux of $\left[{ }^{3} \mathrm{H}\right]-\mathrm{MX}$ in cells over-expressing ABCG2}

As shown in Fig. 2 (A and B), the intracellular accumulation of $\left[{ }^{3} \mathrm{H}\right]-\mathrm{MX}$ was significantly higher in NCI-H460 and HEK293/pcDNA3.1 cells than that in ABCG2 overexpressing NCI-H460/MX20, ABCG2482-R2, ABCG2-482-G2, and ABCG2-482-T7 cells. Icotinib $(1.0$ and $5.0 \mu \mathrm{M})$ significantly increased intracellular accumulation of $\left[{ }^{3} \mathrm{H}\right]-\mathrm{MX}$ in both the NCI-H460 and NCI-H460/MX20 cells, as well as the ABCG2-482-R2, ABCG2-482-G2, and ABCG2-
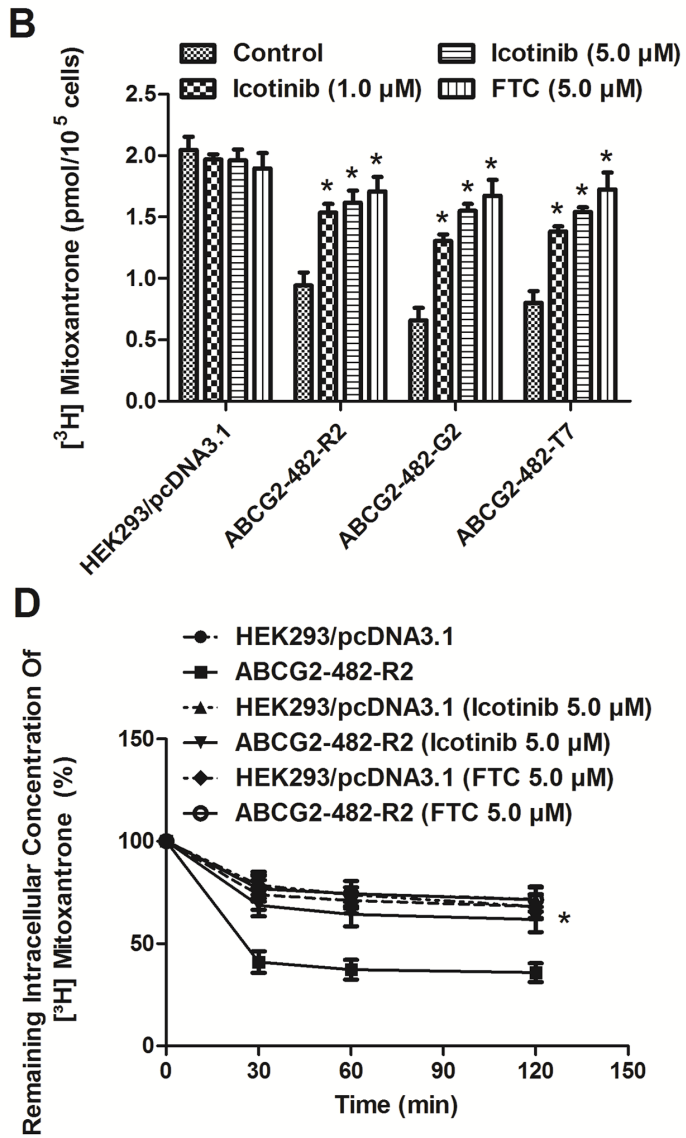

Fig. 2: Effect of Icotinib on the accumulation and efflux of $\left[{ }^{3} \mathbf{H}\right]-\mathbf{M X}$ in ABCG2-expressing cells. Icotinib (at 1.0 and $5.0 \mu \mathrm{M}$ ) significantly increased intracellular accumulation of $\left[{ }^{3} \mathrm{H}\right]-\mathrm{MX}$ in both the NCI-H460 and NCI-H460/MX20 (A) cells, as well as the transfected ABCG2-482-R2, ABCG2-482-G2, and ABCG2-482-T7 cells (B). The efflux activity of ABCG2 was significantly inhibited by $5.0 \mu \mathrm{M}$ of Icotinib at $0,30,60$, and 120 min of treatment in NCI-H460 and NCI-H460/MX20 (C), as well as the ABCG2-482-R2 (D) cells. All values are the mean $\pm \mathrm{SD}$ of 3 assays. Columns, mean; bars, $\mathrm{SD} ;{ }^{*}, P<0.05$, versus the respectively untreated controls. 
482-T7 cells, and its effects were well comparable to that of FTC $(5.0 \mu \mathrm{M})$. However, no change was seen in HEK293/pcDNA3.1 cells. In order to determine whether Icotinib could inhibit the drug efflux function of $\mathrm{ABCG} 2$, we examined the efflux of $\left[{ }^{3} \mathrm{H}\right]-\mathrm{MX}$ in ABCG2-overexpressing cells. As shown in Fig 2 (C and D), the time course of release of $\left[{ }^{3} \mathrm{H}\right]-\mathrm{MX}$ in $\mathrm{ABCG} 2-$ overexpressing cells ABCG2-482-R2 and NCI-H460/
MX20 was significantly higher than that of the HEK293/ pcDNA3.1 and NCI-H460 cells, respectively. However, Icotinib at $5.0 \mu \mathrm{M}$ significantly inhibited the efflux of $\left[{ }^{3} \mathrm{H}\right]-\mathrm{MX}$ at different time points $(30,60$, and $120 \mathrm{~min})$ of treatment in NCI-H460/MX20 and ABCG2-482-R2 cells, as well as the NCI-H460 cells, but showed no apparent effect in the treatment of parental HEK293/pcDNA3.1 cells.

A
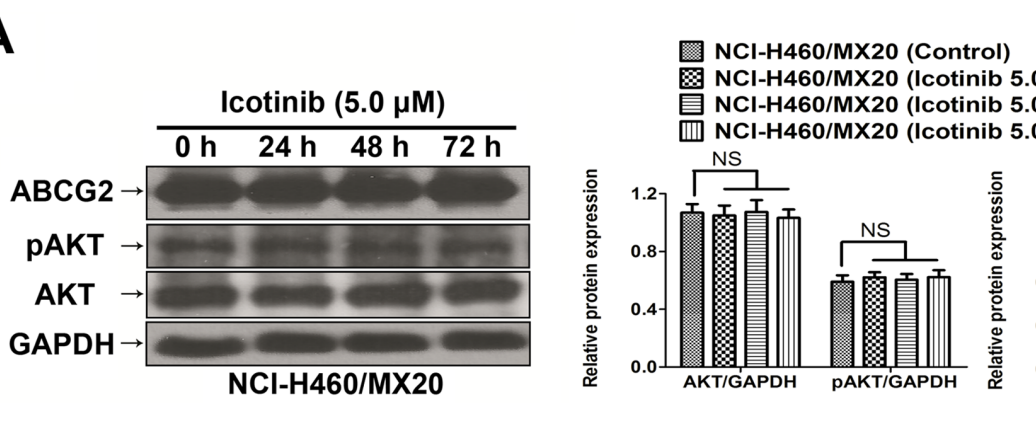

B
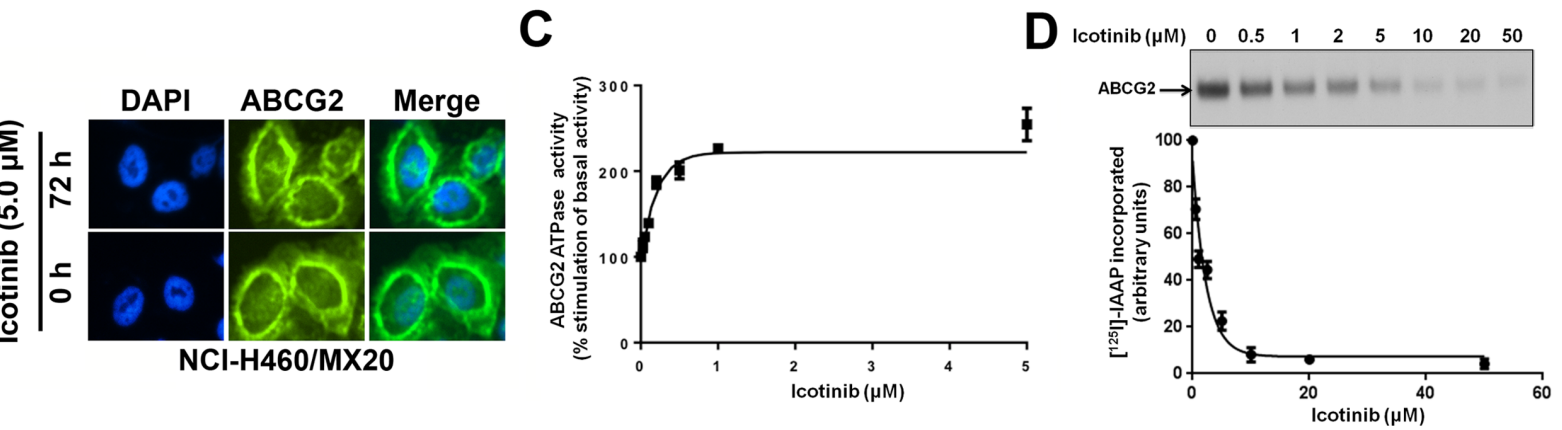

E
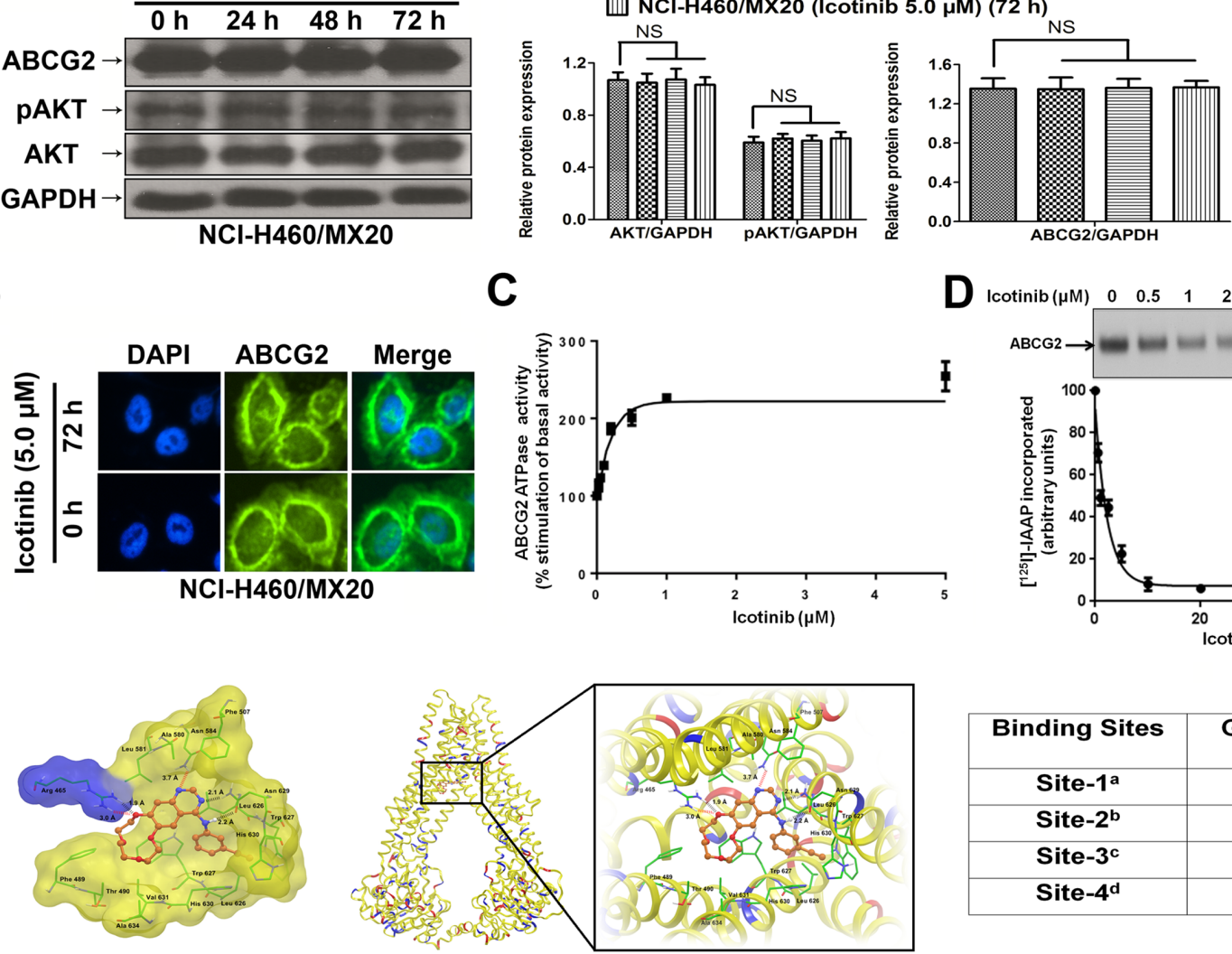

\begin{tabular}{|c|c|}
\hline Binding Sites & $\begin{array}{c}\text { Glide Score } \\
\text { (kcal/mol) }\end{array}$ \\
\hline Site-1 $^{\mathbf{a}}$ & -5.68 \\
\hline Site-2 $^{\mathbf{b}}$ & -6.98 \\
\hline Site-3 $^{\mathbf{c}}$ & -4.52 \\
\hline Site-4 $^{\mathbf{d}}$ & -3.44 \\
\hline
\end{tabular}

Fig. 3: The effect of Icotinib on the expression levels of pAKT, total AKT, ABCG2, the subcellular localization of ABCG2, ATPase activity, the photoaffinity labeling with [ $\left.{ }^{125} \mathrm{I}\right]-\mathrm{IAAP}$, and its docking in the homology model of ABCG2. A. Effect of Icotinib at 5.0 $\mu \mathrm{M}$ on the expression level of pAKT, total AKT, and ABCG2 in NCI-H460/MX20 cell line. The protein levels of AKT, pAKT and ABCG2 were normalized to those of GAPDH in the NCI-H460/MX20 cell lines. Values are the mean \pm SD of 3 assays. Columns, mean; bars, SD; NS, not significant. B. Effect of Icotinib treatment on the subcellular localization of ABCG2 in NCI-H460/MX20 cell. ABCG2 staining is shown in green. DAPI (blue) counterstains the nuclei. C. Effect of Icotinib on the ATPase activity of ABCG2: The BeFx-sensitive specific ATPase activity of ABCG2 was determined in the presence of $0-5 \mu \mathrm{M}$ of Icotinib as described in supplemental methods. The activity in the absence of Icotinib (basal activity) was considered to be $100 \%$, and $\%$-fold stimulation \pm S.D. (Y-axis) was plotted as a function of indicated concentrations of Icotinib (X-axis). D. Effect of Icotinib on the photolabeling of ABCG2 with [25I]-IAAP: Crude membranes from ABCG2 expressing MCF7-FLV1000 cells were photo-crosslinked with $\left.{ }^{125} \mathrm{I}\right]-\mathrm{IAAP}$ in the presence and absence of $0-50 \mu \mathrm{M}$ of Icotinib as described in supplemental methods. [ $\left.{ }^{125} \mathrm{I}\right]-\mathrm{IAAP}$ incorporated in ABCG2 band was quantified using ImageQuant software and plotted as $\%\left[{ }^{125} \mathrm{I}\right]$-IAAP incorporated \pm S.D. (Y-axis) as a function of varying concentration of Icotinib (X-axis). The upper panel shows a representative autoradiogram from three independent experiments and the arrow represents the ABCG2 band photo-crosslinked with $\left.{ }^{125} \mathrm{I}\right]$-IAAP. E. XP Glide predicted binding model of Icotinib with homology modeled ABCG2. The docked conformation of Icotinib as ball and stick model is shown within the large drug-binding cavity of ABCG2. Important amino acids are depicted as sticks with the atoms colored as carbon-green, hydrogen-white, nitrogen-blue, oxygen-red, whereas Icotinib is shown with the same color scheme as above except carbon atoms are represented in orange. Dotted black line indicates hydrogen bonding interactions, whereas dotted red line indicates electrostatic interactions. Left: ABCG2 is represented as Macromodel surface based on residue charge (hydrophobic-yellow, basic-blue). Middle: ABCG2 is represented as protein ribbons based on residue charge (hydrophobic-yellow, basic-blue, acidic-red). Right: Binding energies of Icotinib within each of the predicted binding sites of ABCG2. ${ }^{\text {a Site }}$ grid generated using Arg482; ${ }^{b}$ Site grid generated using Asn629; 'Site grid generated using Arg383; ${ }^{\mathrm{S}}$ Site grid generated using Leu241 and Gly83. 


\section{Effect of Icotinib on the protein expression of AKT, pAKT, ABCG2 and the cellular localization of ABCG2}

The expression levels of ABCG2 were examined to evaluate if Icotinib could alter the expression levels of ABCG2 and its related prosurvival kinase AKT (Fig. $3 \mathrm{~A})$. Our results found that the protein expression levels of ABCG2 and pAKT were not significantly different from that in the ABCG2 overexpressing NCI-H460/MX20 cell line, when treated with Icotinib $(5.0 \mu \mathrm{M})$ at 24,48 and $72 \mathrm{~h}$ compared with the untreated cells. Furthermore, the immunofluorescence assay showed that, with up to $72 \mathrm{~h}$ treatment of Icotinib at $5.0 \mu \mathrm{M}$, Icotinib did not significantly modulate the re-localization of $\mathrm{ABCG} 2$ from cell membrane to internal compartments in the NCI-H460/ MX20 cells (Fig. 3B).

\section{Icotinib interacts at the drug-binding pocket of ABCG2}

The above data indicated that Icotinib might inhibit the ABCG2-mediated efflux of the cytotoxic drugs by binding to the drug-binding pocket of the ABCG2 transporter. To further confirm Icotinib's interaction with ABCG2, its effect was evaluated on the photocrosslinking of ABCG2 with [ $\left.{ }^{125} \mathrm{I}\right]$-Iodoarylazidoprazosin (IAAP) (an ABCG2 substrate) and ATPase activity of this transporter. As shown in Fig. $3 \mathrm{C}$ and D, Icotinib inhibited the photo-crosslinking of $\mathrm{ABCG} 2$ with $\left[{ }^{125} \mathrm{I}\right]-$ IAAP in a concentration-dependent manner with an $\mathrm{IC}_{50}$ value of $1.61 \mu \mathrm{M}$ and stimulated the ATPase activity of this transporter in a concentration-dependent manner with a maximal stimulation of 2.54-fold. The concentration of Icotinib required for $50 \%$ of maximal stimulation was 0.14 $\mu \mathrm{M}$. These results demonstrated that similar to other TKIs,

$$
\text { A }
$$
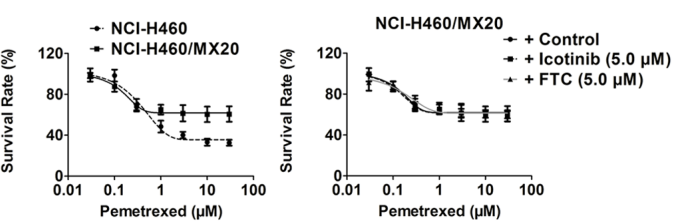

C

$\mathrm{NCl}-\mathrm{H} 460 / \mathrm{MX20} / \mathrm{lcotinib}(0-30 \mu \mathrm{M})$ $\mathrm{NCl}-\mathrm{H} 460 / \mathrm{MX20} / \mathrm{Pemetrexed}(0-300 \mu \mathrm{M})$ $\mathrm{NCl}-\mathrm{H} 460 / \mathrm{MX} 20 / / \mathrm{cotinib}(0-30 \mu \mathrm{M})$

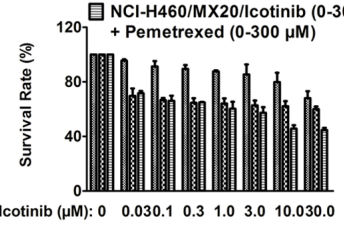

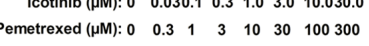

E

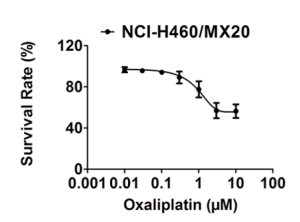

Icotinib $(\mu \mathrm{M}):-10 \quad 30$ ABCG2 TS GAPDH

\section{F}

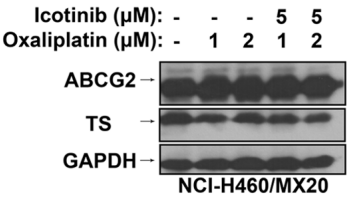

B

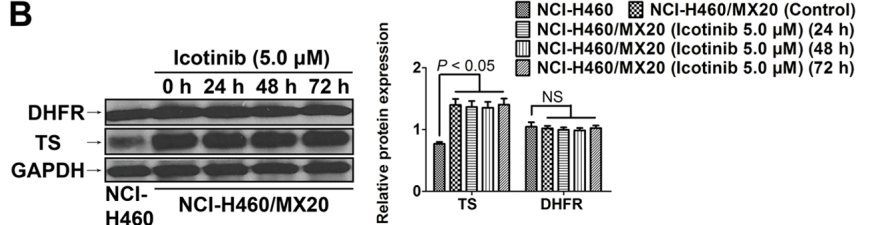

D Pemetrex E2F-1 $\rightarrow-25$

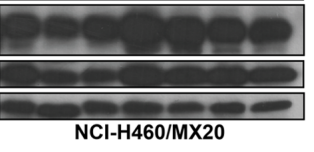

Control Oxaliplatin $(1.0 \mu \mathrm{M})$
Oxaliplatin $(2.0 \mu \mathrm{M})$
Icotinib $(5.0 \mu \mathrm{M})+$ Oxaliplatin $(1.0 \mu \mathrm{M})$
Icotinib $(5.0 \mu \mathrm{M})+$ Oxaliplatin $(2.0 \mu \mathrm{M})$

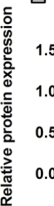
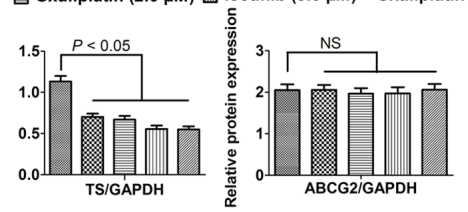
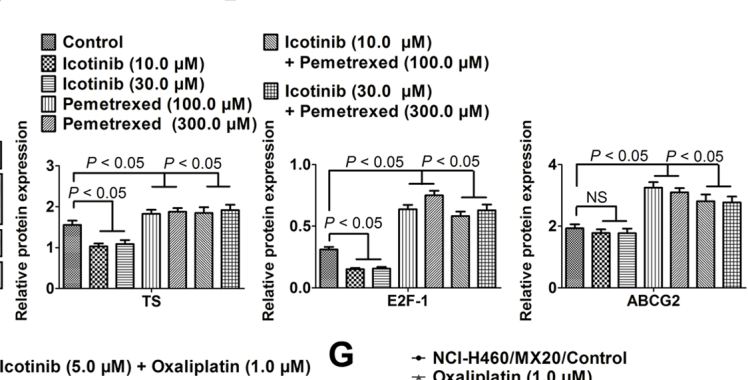

- NCl-H460/MX20/Cont
- Oxaliplatin $(1.0 \mu \mathrm{M})$ Oxaliplatin $(2.0 \mu \mathrm{M})$ Icotinib $(5.0 \mu \mathrm{M})+$ Oxaliplatin $(1.0 \mu \mathrm{M})$ $\Xi^{120} \rightarrow$ Icotinib $(5.0 \mu \mathrm{M})+$ Oxaliplatin $(1.0 \mu \mathrm{M})$

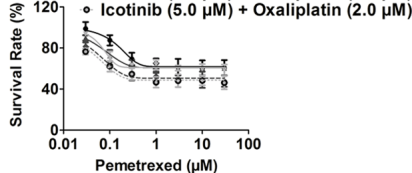

Fig. 4: Icotinib did not sensitize NCI-H460/MX20 cells to pemetrexed. A. The cytotoxicity effect of pemetrexed in the NCI-H460 and NCI-H460/MX20 cell lines. Icotinib (at $5.0 \mu \mathrm{M}$ ) did not significantly reverse pemetrexed resistance in the NCI-H460/MX20 cells. B. Western blot analysis was conducted to examine the expression levels of TS and DHFR between the NCI-H460 and NCI-H460/MX20 cell lines. NCI-H460/MX20 cells were treated with Icotinib at 5.0 $\mu \mathrm{M}$ up to $72 \mathrm{~h}$. The protein levels of TS and DHFR were normalized to those of GAPDH in the NCI-H460 and NCI-H460/MX20 cell lines. Values are the mean \pm SD of 3 assays. Columns, mean; bars, SD; NS, not significant. C. The cytotoxicity effect of combined serial concentrations of Icotinib $(0-30 \mu \mathrm{M})$ with pemetrexed $(0-300 \mu \mathrm{M})$ in NCI-H460/ MX20 cells. Icotinib $(30 \mu \mathrm{M})$ plus pemetrexed $(300 \mu \mathrm{M})$ did not induce more synergistic effect than a combination of Icotinib $(10 \mu \mathrm{M})$ plus pemetrexed $(100 \mu \mathrm{M})$. D. Western blot analysis to examine the expression levels of TS, ABCG2 and E2F-1 when treated with either Icotinib alone (at $10 \mu \mathrm{M}$ and $30 \mu \mathrm{M}$ ), pemetrexed alone (at $100 \mu \mathrm{M}$ and $300 \mu \mathrm{M}$ ), or their combination. The protein levels of TS, ABCG2 and E2F-1 were normalized to those of GAPDH. Values are the mean \pm SD of 3 assays. Columns, mean; bars, SD. E. The cytotoxicity effect of oxaliplatin in the NCI-H460/MX20 cell line. F. Western blot analysis was conducted to examine the expression levels of TS and ABCG2 when treated with either oxaliplatin alone $(1.0$ or $2.0 \mu \mathrm{M})$, or Icotinib $(5.0 \mu \mathrm{M})$ and oxaliplatin $(1.0$ or $2.0 \mu \mathrm{M})$ combination. The protein expression levels of TS and ABCG2 were normalized to those of GAPDH. Values are the mean \pm SD of 3 assays. Columns, mean; bars, SD. G. The cytotoxicity effect of pemetrexed when combined with either oxaliplatin alone $(1.0$ or $2.0 \mu \mathrm{M})$, or Icotinib $(5.0 \mu \mathrm{M})$ and oxaliplatin $(1.0$ or $2.0 \mu \mathrm{M})$ combination. Oxaliplatin alone $(1.0$ or $2.0 \mu \mathrm{M})$ could not significantly reverse pemetrexed resistance. However, the combination of Icotinib $(5.0 \mu \mathrm{M})$ with oxaliplation $(1.0$ or $2.0 \mu \mathrm{M})$ could significantly enhance the chemosensitivity of pemetrexed in the NCI-H460/MX20 cells. 
Icotinib also interacts at the substrate-binding pocket of ABCG2.

\section{Docking of Icotinib in the homology model of ABCG2}

The highest score docked model of Icotinib at Asn629 centroid grid of ABCG2 showed the importance of hydrophobic and hydrogen-bonding interactions (Fig. 3E). The 3-ethinylphenyl ring was stabilized by nearby residues Leu626, Trp627 and His630 through hydrophobic interactions. The backbone of Asn629 formed two hydrogen bonding interactions with the -NH-

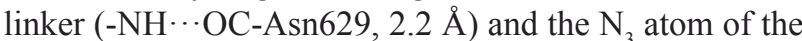
quinazoline ring $\left(\mathrm{N}_{3} \cdots \mathrm{H}_{2} \mathrm{~N}-\mathrm{Asn} 629,2.1 \AA\right)$. Quinazoline ring was stabilized by the side chains of Phe507, Ala580, Leu581, Asn584, Leu626 and Try627. The $\mathrm{N}_{1}$ atom of quinazoline ring formed an electrostatic interaction with the side chain amino group of Asn584 $\left(\mathrm{N}_{1} \cdots \mathrm{H}_{2} \mathrm{~N}-\right.$ Asn584, $3.7 \AA$ ). The 2, 3, 5, 6, 8, 9-hexahydro-1, 4, 7, 10-tetraoxacyclododecanol ring was stabilized by Thr490, Phe489, Val631 and Ala634. The $\mathrm{O}_{1}$ atom of this macrocycle interacted with the guanidine group of $A r g 465$ by both hydrogen-bonding interaction $\left(\mathrm{O}_{1} \cdots \mathrm{H}_{2} \mathrm{~N}-\mathrm{Arg} 465\right.$, $1.9 \AA)$ and electrostatic interaction $\left(\mathrm{O}_{1} \cdots \mathrm{H}_{2} \mathrm{~N}-\mathrm{Arg} 465,3.0\right.$ $\AA)$.

\section{Inhibition of ABCG2 function by Icotinib did not sensitize NCI-H460/MX20 cells to pemetrexed}

As shown in Fig. 4A, NCI-H460/MX20 showed high resistance to the pemetrexed compared to that of the parental cells NCI-H460. However, Icotinib at $5 \mu \mathrm{M}$ did not significantly reverse pemetrexed resistance in the NCI-H460/MX20 cells. Interestingly, the expression of thymidylate synthase (TS) was significant higher in the NCI-H460/MX20 cell line than in the NCI-H460 cells. Moreover, the TS expression was not significantly altered after treatment with Icotinib $(5 \mu \mathrm{M})$ up to $72 \mathrm{~h}$. However, the expression of dihydrofolate reductase (DHFR) was not significantly different between these two cell lines (Fig. 4B). Furthermore, when serial concentrations of Icotinib $(0 \sim 30 \mu \mathrm{M})$ were combined with those of pemetrexed $(0 \sim 300 \mu \mathrm{M})$, the more synergistic cytotoxicity of Icotinib and pemetrexed combination was not detected when compared Icotinib $(30 \mu \mathrm{M})$ plus pemetrexed $(300 \mu \mathrm{M})$ with Icotinib $(10 \mu \mathrm{M})$ plus pemetrexed $(100 \mu \mathrm{M})$ (Fig. 4C). More interestingly, Icotinib alone (at 10 and 30 $\mu \mathrm{M}$ ) could significantly reduce TS expression, possibly through E2F-1 reduction. However, pemetrexed alone (at 100 and $300 \mu \mathrm{M}$ ) could significantly induce TS and ABCG2 expression. Nevertheless, the expression of TS was not additionally reduced by Icotinib and pemetrexed combination (Fig. 4D). Furthermore, previous study had shown that oxaliplatin could down-regulate the expression of TS [19]. In our study, oxaliplatin at the non-toxic concentration (1.0 and $2.0 \mu \mathrm{M})$ (Fig. 4E), could inhibit the TS expression in the NCI-H460/MX20 cells (Fig. 4F). The combination of Icotinib $(5.0 \mu \mathrm{M})$ with oxaliplation $(1.0$ or $2.0 \mu \mathrm{M}$ ) could significantly enhance the chemosensitivity of pemetrexed in the NCI-H460/MX20 cells (Fig. 4G)

\section{Therapeutic effect of Icotinib combined with pemetrexed or topotecan in vivo NCI-H460/MX20 tumor xenografts}

As shown in Fig. 5A and $\mathrm{B}$, treatment with topotecan as a single agent exhibited a significant suppression of tumor growth $(P<0.01)$. The inhibition rate of topotecan alone was $46.3 \%$. The ratio of growth inhibition by pemetrexed alone is $8.2 \%$, whereas it was not significantly different compared with the control group $(P=0.18)$. Treatment with Icotinib alone also did not significantly decrease the tumor weight $(P=0.38)$. Strikingly, a combination of Icotinib and topotecan showed a dramatic synergistic anticancer effect when compared with either treatment of topotecan or Icotinib alone. The Icotinib and topotecan combination reduced the averaged tumor size by $70.5 \%(P<0.01)$. However, the synergistic anticancer effect was not detected when the combination of Icotinib and pemetrexed compared with the control group $(P=0.28)$. Moreover, the in vivo therapeutic effect of Icotinib combined with pemetrexed or topotecan was further confirmed by the flat tumor growth curve (Fig. 5C). The Icotinib and topotecan combination caused a slight decrease in body weight, but this effect was not statistically significant (Fig. 5D). Moreover, Immunohistochemistry (IHC) analysis of the excised tumors showed that the expression of ABCG2 was not significantly different among 6 treatment groups (Fig. 5E).

\section{DISCUSSION}

In the present study, we showed for the first time that Icotinib potentiated the chemosensitivity of established ABCG2 substrates in ABCG2-overexpressing cells. Icotinib treatment significantly increased the intracellular accumulation of $\left[{ }^{3} \mathrm{H}\right]-\mathrm{MX}$ in both the NCI-H460 and NCI-H460/MX20 cell lines. Moreover, previous studies have found that the Arg482- to G482- or Thr482-ABCG2 mutation altered substrate specificity $[20,21]$. Our results found that like FTC, Icotinib significantly enhanced the chemosensitivity of ABCG2 substrates in both the cells with wild-type Arg 482 and mutant-type G482 or Thr482 of ABCG2. Furthermore, Icotinib could not reverse ABCB1, and $\mathrm{ABCC} 10$-mediated drug resistance, indicating that the reversal effect of Icotinib might attribute to its specific effect on the overexpression of ABCG2.

In human tumors, EGFR plays a crucial role in the biological behavior of NSCLC [22], and the 
overexpression of the EGFR is associated with the response to anti-EGFR agents [23]. Pick, A et al. [24] found that EGFR might exert a post-transcriptional enhancing effect on ABCG2 expression via the PI3K/AKT signaling pathway, and EGFR inhibitors might influence ABCG2 expression in EGFR-positive MDCK ABCG2 cells. Moreover, Goler-Baron, V et al. [25] reported that PI3K-AKT signaling pathway was a key regulator of subcellular localization of ABCG2 and functional MDR. Inhibition of AKT signaling pathway might result in relocation of $\mathrm{ABCG} 2$ from the cell membrane to the intracellular compartment $[25,26]$. Icotinib is an inhibitor of EGFR, which might indirectly modulate the phosphorylation of AKT via EGFR and its downstream signal pathway, and can further influence the ABCG2 expression thereby reversing ABCG2-mediated MDR.

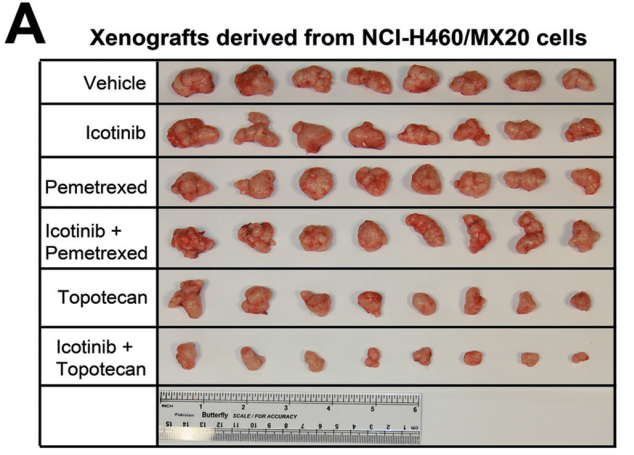

\section{C}

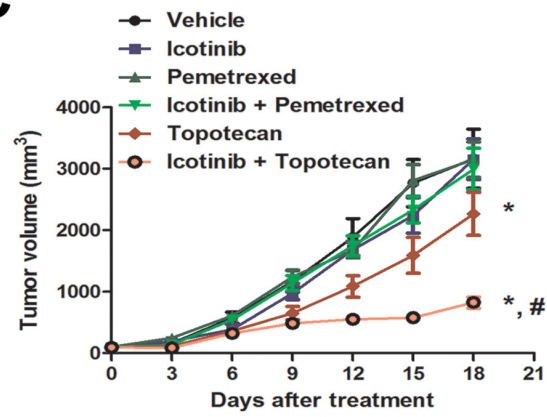

$\mathbf{E}$

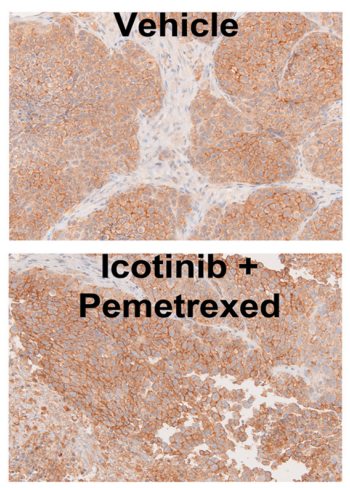

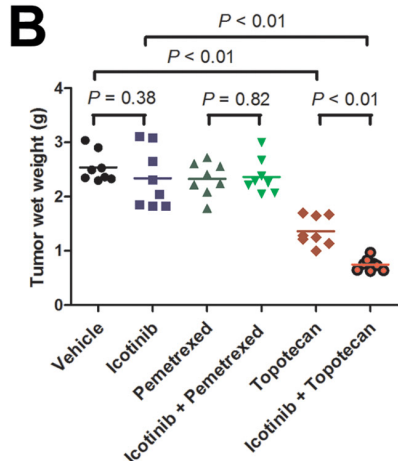

D

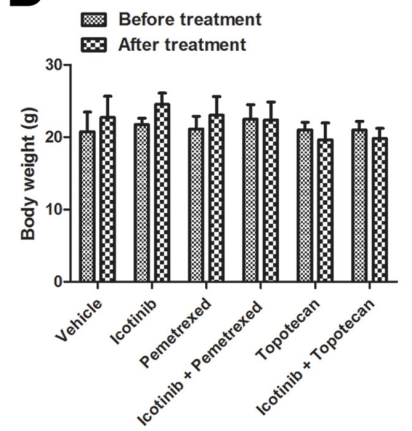

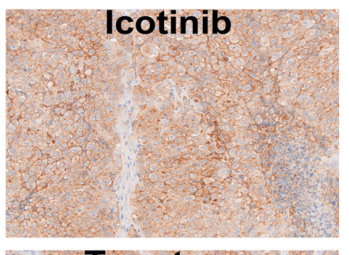
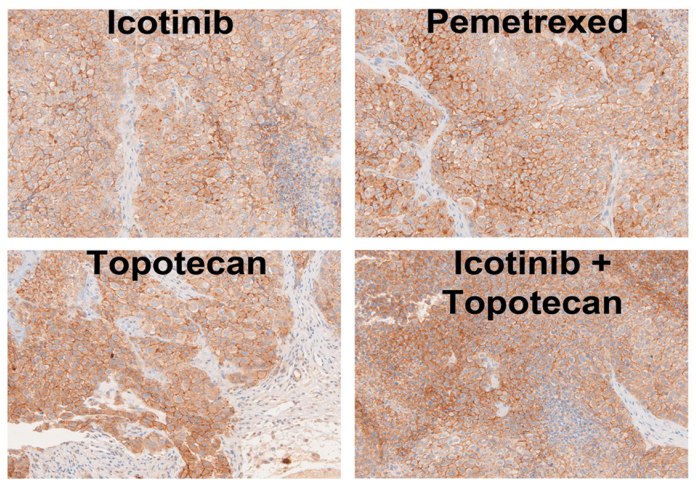

Fig. 5: Therapeutic effect of Icotinib combined with pemetrexed or topotecan in a xenograft model of NCI-H460/MX20 cells in athymic nude mice. The doses of each group were as follows: vehicle $(\mathrm{q} 3 \mathrm{~d} \times 6)$; Icotinib $(60 \mathrm{mg} / \mathrm{kg}$, p.o., q3d $\times 6)$; pemetrexed $(100$ $\mathrm{mg} / \mathrm{kg}$, i.p., q3d $\times 6$ ); Icotinib $(60 \mathrm{mg} / \mathrm{kg}$, p.o., q3d × 6, given $2 \mathrm{~h}$ before giving pemetrexed $)+$ pemetrexed $(100 \mathrm{mg} / \mathrm{kg}, \mathrm{i} . \mathrm{p}$., q3d $\times 6)$; topotecan $(3.0 \mathrm{mg} / \mathrm{kg}$, i.p., $\mathrm{q} 3 \mathrm{~d} \times 6)$; and Icotinib $(60 \mathrm{mg} / \mathrm{kg}$, p.o., $\mathrm{q} 3 \mathrm{~d} \times 6$, given $2 \mathrm{~h}$ before giving topotecan $)+$ topotecan $(3.0 \mathrm{mg} / \mathrm{kg}$, i.p., $\mathrm{q} 3 \mathrm{~d} \times 6)$. A. The tumors were excised and weighed, and the representative pictures of each group were taken after 18 days of treatment. B. Tumor weights $(\mathrm{n}=8)$ of 6 groups are represented as each dot. Solid lines indicate the mean of each group. $P$ values were calculated using the Student's t-test. C. The tumor volumes were measured every 3 days, and the tumor growth curve was created for each group $(\mathrm{n}=8)$. Dots, mean tumor volume; bars, $\mathrm{SD} ;{ }^{*}, P<0.01$ versus the vehicle group; $\#, P<0.01$ versus topotecan alone group. D. The body weights of mice were measured every 3 days, and changes in the mean body weight before and after treatment are shown in the bar graph. E. Immunohistochemistry analysis of ABCG2 expression in the tumor tissues from 6 groups after 18 days of treatment. ABCG2 specifically expressed in the cell membrane and the expression of ABCG2 was not significantly different among 6 treatment groups. 
However, we found that Icotinib neither significantly alter the protein expression levels of $\mathrm{pAKT}, \mathrm{ABCG} 2$ nor stimulate translocation of $\mathrm{ABCG} 2$, suggesting that the reversal of ABCG2-mediated MDR by Icotinib might be through inhibition of its transport activity, rather than modulation of the subcellular protein expression or translocation.

Tyrosine kinase inhibitors are known to interact at the substrate-binding pocket of $\mathrm{ABC}$ transporters [27]. The data from photo-crosslinking of ABCG2 with [ $\left.{ }^{125} \mathrm{I}\right]-\mathrm{IAAP}$ and ATPase activity of ABCG 2 demonstrate that Icotinib, similarly to other TKIs, interacts at the substrate-binding pocket of this transporter. The concentration of Icotinib required for $50 \%$ stimulation of maximal ABCG2 ATPase activity was $0.14 \mu \mathrm{M}$, suggesting that it has a relatively higher affinity for interaction at the substrate-binding pocket of this transporter compared to other TKIs [27]. Furthermore, docking simulations suggested several strong interactions between Icotinib and ABCG2 homology model, which was consistent with our experimental data. Predicted best-docked model at Asn629 grid may explain its insensitivity to Arg482 mutations. These strong contacts may be induced by previously illustrated essential pharmacophoric features for ABCG2 binding [28].

Recently, Yoh K et al. [10] demonstrated that overexpression of $\mathrm{ABCG} 2$ appeared to be a predictor of shorter survival in patients with advanced NSCLC. Currently, pemetrexed/cisplatin is a standard regimen for first-line treatment of advanced non-squamous NSCLC [11]. However, some studies report that pemetrexed is a substrate of ABCG2 [12,13], which implies that blocking ABCG2-mediated active efflux function might substantially contribute to increased response rates and prolonged survival in patients with NSCLC [14]. In our study, we found that the ABCG2-overexpressing NCI-H460/MX20 cells showed high resistance to the pemetrexed compared to the parental cell NCI-H460. However, Icotinib at $5.0 \mu \mathrm{M}$ did not significantly reverse pemetrexed resistance in the NCI-H460/MX20 cells. Interestingly, we found that the TS expression, which was another major factor that mediated pemetrexed resistance [29], was significant higher in the NCI-H460/MX20 cells than in the NCI-H460 cells, and that in both these cell lines, the expression levels of TS were consistent with the expression of ABCG2. To the best of our knowledge, this is the first report to show that the up-regulation of TS in the MX-selected derivative ABCG2-overexpressing cell line NCI-H460/MX20. In the previous study, Salnikov et al. [30] found a significant association between the expression of TS and CD133, which represents a marker of tumor-initiating cells in NSCLC, and was co-expression of ABCG2 in subpopulation of NSCLC patients [31]. However, this co-upregulation phenomenon needs to be confirmed in other ABCG2-overexpressing cell lines, and the mechanism that mediates both the ABCG2 and TS upregulation still needs to be examined in our further studies.
Until now, no predictive biomarkers to the combination of EGFR-TKIs with chemotherapy have been identified. In our study, we determined that ABCG2 might be a potential biomarker for the clinical outcome to a combination of Icotinib with ABCG2 substrates in patients with NSCLC. To determine whether the reversal efficacy of Icotinib in vitro could be extended to an in vivo xenografts model, we investigated the potentiation of Icotinib on the antitumor activity of topotecan or pemetrexed in NCI-H460/MX20 tumor xenograft model. Our results found that the combination of Icotinib with topotecan markedly enhanced antitumor activity of topotecan in the ABCG2-overexpressing NCI-H460/ MX20 tumor xenografts model when compared to either the Icotinib or topotecan treatment alone. However, the synergistic antitumor activity was not observed in treatment with Icotinib and pemetrexed, which might be due to the inefficiency of Icotinib in overcoming the additional up-regulation of TS in the NCI-H460/MX20 tumor xenografts. In the previous study, Giovannetti et al. [32] found that Erlotinib and pemetrexed showed a strong synergism in NSCLC cells, possibly via the combination decreased TS expression and E2F-1. However, in our study, we found that Icotinib alone could significantly reduce TS expression, possibly through E2F-1 reduction. Pemetrexed alone could significantly increase the TS and ABCG2 expression. Nevertheless, the TS and ABCG2 expression were not reduced by Icotinib and pemetrexed combination, which finally led to the pemetrexed resistance in the NCI-H460/MX20 cells and xenografts. Furthermore, our results showed that the TS upregulation could be overcome by oxaliplatin, and that the combination of oxaliplatin with Icotinib could significantly reverse pemetrexed resistance in the NCI-H460/MX20 cells. Our results suggested the inhibition of both the TS and ABCG2 expressions might contribute to the ability to overcome the resistance of pemetrexed in the TS- and ABCG2-overexpressing NSCLC patients.

In conclusion, the present study showed that Icotinib significantly reversed ABCG2-mediated MDR by directly inhibiting the drug transport activity of ABCG2. Combination of Icotinib and topotecan exhibited significant synergistic anticancer activity against the ABCG2-overexpressing NCI-H460/MX20 cells both in vitro and in vivo. Antagonizing the activity of ABCG2 was insufficient to overcoming pemetrexed resistance in NCI-H460/MX20 cells and xenografts, probably due to the co-upregulation of TS and ABCG2. Our study identified a promising therapeutic strategy in overcoming ABCG2-mediated drug resistance in NSCLC. However, the mechanism that up-regulated both the TS and ABCG2 in the MX-selected derivative ABCG2-overexpressing NSCLC cell line NCI-H460/MX20 needs to explored in further studies. 


\section{METHODS}

\section{Materials}

Icotinib (Fig. 1A) was a product of Selleck Chem Inc (Houston,TX, USA). For the animal study, Icotinib hydrochloride tablets were a gift from Zhejiang Beta Pharma, Inc, China. MX, SN-38, topotecan, pemetrexed, vincristine, cisplatin, oxaliplatin, verapamil, dimethyl sulfoxide (DMSO) and 3-(4, 5-dimethylthiazole-2yl)-2, 5-biphenyl tetrazolium bromide (MTT) and other chemicals were purchased from Sigma Chemical Co (St. Louis, MO, USA). [ $\left.{ }^{125} \mathrm{I}\right]-\mathrm{IAAP}(2,200 \mathrm{Ci} / \mathrm{mmol})$ was purchased from PerkinElmer Life and Analytical Sciences (Waltham, MA). Cepharanthine was provided by Kakenshoyaku Co. (Tokyo, Japan). FTC was provided by Dr. Susan E. Bates from NIH (Bethesda, Maryland, USA).

\section{Cell lines and cell culture}

HEK293/pcDNA3.1, wild-type ABCG2-482-R2, mutant ABCG2-482-T7 and mutant ABCG2-482-G2 cells were established by transfecting HEK293 cell with either the empty pcDNA3.1 vector or pcDNA3.1 vector containing a full-length ABCG2, with coding arginine (R), threonine (T), or glycine (G) at amino acid position 482 , respectively after selection with G418 and maintenance in the medium with $2 \mathrm{mg} / \mathrm{ml}$ of G418 [21]. HEK/ABCB1 and $\mathrm{HEK} / \mathrm{ABCC} 10$ cell lines were generated by selection with G418 (2 mg/ml) after transfecting HEK293 cell with $\mathrm{ABCB} 1$ vector or $\mathrm{ABCC} 10$ vector, respectively [33]. The human lung cancer cell line NCI-H460 and its MX-selected derivative ABCG2-overexpressing cell line NCI-H460/MX20 and A549 cell line were grown as described previously [34]. The wild-type ABCG2overexpressing cell line MCF-7/Flv1000 was maintained with $1,000 \mathrm{nmol} / \mathrm{L}$ of flavopiridol [35]. All cell lines were maintained in RPMI 1640 or DMEM medium (Hyclone Co., South Logan, Utah, USA), containing $10 \%$ fetal bovine serum and $1 \%$ penicillin/streptomycin and cultured at $37{ }^{\circ} \mathrm{C}$ in the incubator with $5 \% \mathrm{CO} 2$.

\section{MTT cytotoxicity assay}

Cytotoxicity tests and reversal experiments were performed using the MTT colorimetric assay as described previously [36]. Cells were harvested and resuspended in a final concentration of $6 \times 10^{3}$ cells/well for the HEK293/pcDNA3.1, HEK/ABCB1, HEK/ABCC10, ABCG2-482-R2, ABCG2-482-T7 and ABCG2-482-G2 cells, and $4 \times 10^{3}$ cells/well for the A549, NCI-H460 and NCI-H460/MX20 cells. Cells were evenly seeded into 96well microtiter plates. After $24 \mathrm{~h}$, various concentrations of Icotinib, pemetrexed and oxaliplatin were added into the each well. To evaluate the synergistic cytotoxic activity of Icotinib and pemetrexed combination, serial concentrations of Icotinib $(0 \sim 30 \mu \mathrm{M})$ and pemetrexed $(0 \sim 300 \mu \mathrm{M})$ were added simultaneously into each well. For the reversal experiments, various concentrations of chemotherapeutic drugs were added into designated wells after $2 \mathrm{~h}$ of preincubation with Icotinib, FTC, verapamil or cepharanthine. Then MTT solutions $(4 \mathrm{mg} / \mathrm{mL})$ were added after $68 \mathrm{~h}$ of incubation. The plate was incubated for an additional $4 \mathrm{~h}$, and then the supernatant was discarded and $100 \mu \mathrm{l}$ of DMSO were added to dissolve the formazan crystals. Cell viability was measured using an OPSYS microplate Reader from DYNEX Technologies, Inc. (Chantilly, VA) at $570 \mathrm{~nm}$ wavelength. All experiments were repeated at least 3 times, and the mean and standard deviation (SD) value were calculated.

\section{$\left[{ }^{3} \mathrm{H}\right]-\mathrm{MX}$ accumulation and efflux assay}

The effect of Icotinib on the intracellular accumulation and efflux of $\left[{ }^{3} \mathrm{H}\right]-\mathrm{MX}$ was examined in ABCG2-overexpressing cells as previous described [37]. Briefly, the cells $\left(5 \times 10^{6} / \mathrm{cells}\right)$ were resuspended and incubated in the RPMI 1640 medium in the presence or absence of Icotinib $(1.0$ and $5.0 \mu \mathrm{M})$ or FTC $(5.0 \mu \mathrm{M})$ at $37^{\circ} \mathrm{C}$ for $2 \mathrm{~h}$. Then cells were incubated with $0.01 \mu \mathrm{M}$ $\left[{ }^{3} \mathrm{H}\right]-\mathrm{MX}$ containing medium for an additional $2 \mathrm{~h}$ at 37 ${ }^{\circ} \mathrm{C}$, with or without Icotinib $(1.0$ and $5.0 \mu \mathrm{M})$ or FTC $(5.0 \mu \mathrm{M})$, and subsequently washed twice with ice-cold PBS. For accumulation assays, cells were lysed by the $10 \mathrm{mM}$ lysis buffer (pH 7.4, containing 1\% Triton X-100 and $0.2 \% \mathrm{SDS}$ ) and then placed in scintillation fluid. For the efflux assay, the suspended cells were continued to culture in the $\left[{ }^{3} \mathrm{H}\right]-\mathrm{MX}$ free medium with or without Icotinib $(5.0 \mu \mathrm{M})$ or FTC $(5.0 \mu \mathrm{M})$ at $37^{\circ} \mathrm{C}$. The aliquots of cells were harvested at the indicated times $(0,30,60$, and $120 \mathrm{~min}$ ), and then washed with ice-cold PBS and transferred to scintillation vials. The radioactivity was measured using the Packard TRI-CARB1 1900CA liquid scintillation analyzer from Packard Instrument Company, Inc (Downers Grove, IL). [ $\left.{ }^{3} \mathrm{H}\right]-\mathrm{MX}(23 \mathrm{Ci} / \mathrm{mmol})$ was a product of Moravek Biochemicals, Inc (Brea, $\mathrm{CA}$ ).

\section{Western blot analysis}

Western blotting was performed as previous described [38]. Monoclonal ABCG2 antibody (BXP-21) (sc-58222), DHFR antibody (E-18) (sc-14778) and the secondary horseradish peroxidase-labeled anti-mouse IgG were purchased from Santa Cruz Biotechnology, Inc. (Santa Cruz, CA). AKT (pan) (C67E7) Rabbit mAb \#4691, phospho-AKT (Thr308) (C31E5E) Rabbit mAb \#2965, E2F-1 Rabbit mAb \#3742, Thymidylate synthase (D5B3) Rabbit mAb \#9045, GAPDH (D16H11) Rabbit mAb 
\#5174 and the secondary horseradish peroxidase-labeled anti-rabbit IgG were purchased from Cell Signaling Technology Inc (USA). Protein quantified expression was measured by ImageJ 1.47 Software (NIH, USA).

\section{Immunofluorescence}

The immunofluorescence assay was carried out as described previously [39]. Cells $\left(1 \times 10^{4}\right)$ were seeded into the 96-well plate and cultured with medium containing Icotinib $(5.0 \mu \mathrm{M})$. After $72 \mathrm{~h}$ of incubation, cells were fixed with $4 \%$ paraformaldehyde (15 $\mathrm{min}$ ) after washed with PBS, and then blocked with the BSA $(2 \mathrm{mg} / \mathrm{ml})$ for $1 \mathrm{~h}$, followed by incubation with monoclonal antibody BXP-21 (against ABCG2) (1:200 dilution) overnight. Alexa flour 488-conjugated goat anti-mouse IgG (1:1000) (Molecular Probes, Carlsbad, CA) was used as the secondary antibody. Cell nuclei were counterstained by DAPI. Immunofluorescence images were caught by inverted microscope (model IX70; Olympus, Center Valley, PA) with IX-FLA fluorescence and CCD camera.

\section{ABCG2 ATPase assay}

Crude membrane protein $(100 \mu \mathrm{g}$ protein $/ \mathrm{mL})$ from High-five cells expressing ABCG2 was incubated at $37^{\circ} \mathrm{C}$ with the indicated concentration of Icotinib in the presence and absence of beryllium fluoride $(0.2 \mathrm{mmol} / \mathrm{L}$ beryllium sulfate and $2.5 \mathrm{mmol} / \mathrm{L}$ sodium fluoride) in ATPase assay buffer $\left(50 \mathrm{mmol} / \mathrm{L} \mathrm{KCl}, 5 \mathrm{mmol} / \mathrm{L} \mathrm{NaN}_{3}, 2 \mathrm{mmol} / \mathrm{L}\right.$ EGTA, $10 \mathrm{mmol} / \mathrm{L} \mathrm{MgCl}_{2}, 1 \mathrm{mmol} / \mathrm{L} \mathrm{DTT}$, $\mathrm{pH}$ 6.8) for $10 \mathrm{~min}$. The specific ATPase activity was recorded as beryllium fluoride--sensitive ATPase activity as described previously [40].

\section{Photoaffinity labeling of ABCG2 with $\left[{ }^{125}\right.$ I]-IAAP}

Crude membranes (1 mg protein/mL) from ABCG2expressing MCF-7 FLV1000 cells were incubated with 0 to $50 \mu \mathrm{mol} / \mathrm{L}$ of Icotinib for $10 \mathrm{~min}$ at $21^{\circ} \mathrm{C}$ to $23^{\circ} \mathrm{C}$ in $50 \mathrm{mmol} / \mathrm{L}$ Tris- $\mathrm{HCl}(\mathrm{pH} 7.5)$. The photo-crosslinking of ABCG2 with 3 to $6 \mathrm{nmol} / \mathrm{L}\left[{ }^{125} \mathrm{I}\right]-\mathrm{IAAP}(2,200 \mathrm{Ci} / \mathrm{mmol})$ followed by immunoprecipitation with BXP-21 was done as previously described [40]. Immunoprecipitated ABCG2 protein crosslinked with $\left[{ }^{125} \mathrm{I}\right]$-IAAP was resolved on a $7 \%$ Tris-acetate gel. The incorporation of $\left[{ }^{125} \mathrm{I}\right]$-IAAP into the ABCG2 band was quantified using the STORM 860 PhosphorImager system (Molecular Dynamics) and the software ImageQuaNT, as described [40].

\section{Molecular modeling}

The structures of Icotinib and ABCG2 homology model were refined using our previous protocols [41].
Glide v6.0 (Schrödinger, LLC, New York, NY, 2013) was used with the default functions. All computations were performed on Dell Precision 490n with the Linux OS (Ubuntu 12.04 LTS).

\section{Animals}

Athymic NCR (nu/nu) nude mice, 10 to 15 weeks old and weighing 18 to $22 \mathrm{~g}$ (Taconic Farms (NCRNU-M, Homozygous, Albino color)), were used for the ABCG2 xenograft models. All animals were provided with sterilized water and rodent chow ad libitum and maintained with an alternating $12 \mathrm{~h}$ light/dark cycle. All the experiments were approved by the Institutional Animal Care \& Use Committee (IACUC) of St. John's University, and were carried out in accordance with the guidelines from Animal Welfare Act and The U.S. Public Health Service Policy on Humane Care and Use of Laboratory Animals.

\section{Nude mouse MDR xenograft models}

The ABCG2-overexpressing NSCLC cell NCI-H460/MX20 xenograft models were established as previously described [41]. Briefly, NCI-H460/MX20 cells $\left(4 \times 10^{6}\right)$ were injected subcutaneously under the armpits region of the nude mice. The mice were randomized into 6 groups $(n=8)$ when the tumors reached a mean diameter of $0.5 \mathrm{~cm}$ (day 0 ), and then received treatments as follows: (a) vehicle (saline $+0.5 \%$ Sodium Carboxymethyl Cellulose $(\mathrm{CMC}-\mathrm{Na}))(\mathrm{q} 3 \mathrm{~d} \times 6)$, (b) Icotinib diluted in saline $+0.5 \%$ CMC-Na $(60 \mathrm{mg} / \mathrm{kg}$, p.o., q3d $\times 6)$, (c) pemetrexed $(100 \mathrm{mg} / \mathrm{kg}$, i.p., q3d × 6), (d) Icotinib $(60$ $\mathrm{mg} / \mathrm{kg}$, p.o., $\mathrm{q} 3 \mathrm{~d} \times 6$, given $2 \mathrm{~h}$ before giving pemetrexed) + pemetrexed $(100 \mathrm{mg} / \mathrm{kg}$, i.p., q3d × 6), (e) topotecan $(3.0$ $\mathrm{mg} / \mathrm{kg}$, i.p., $\mathrm{q} 3 \mathrm{~d} \times 6)$, and (f) Icotinib $(60 \mathrm{mg} / \mathrm{kg}$, p.o., $\mathrm{q} 3 \mathrm{~d}$ $\times 6$, given $2 \mathrm{~h}$ before giving topotecan $)+$ topotecan $(3.0$ $\mathrm{mg} / \mathrm{kg}$, i.p., $\mathrm{q} 3 \mathrm{~d} \times 6$ ). The body weights of the mice were monitored and the two perpendicular diameters of tumors ( $A$ and $B$ ) were recorded every 3rd day, the tumor volumes $(V)$ were calculated according to the following formula described previously [41].

$$
V=\frac{\pi}{6}\left(\frac{A+B}{2}\right)^{3}
$$

The ratio of growth inhibition (IR) described previously [41] was estimated according to the formula given below.

$$
\operatorname{IR}(\%)=1-\frac{\text { Mean tumor weight of experimental group }}{\text { Mean tumor weight of control group }} \times 100 \%
$$

\section{Immunohistochemistry (IHC)}

Tumors were collected after 18 days of treatment and Immunohistochemistry were performed as previously 
described [42]. The primary monoclonal antibody against ABCG2 (BXP-21) at the dilution of 1:100 and labeled polymer-HRP anti-mouse (DAKO) secondary antibody were used in the experiment. Nikon Eclipse E600 microscope with NIS Elements D3.0 software was used to catch the image.

\section{Statistics}

Statistical analysis was calculated using the Student's t test. $P<0.05$ was considered statistically significant.

\section{ACKNOWLEDGMENTS}

We gratefully thank late Dr. Gary D. Kruh (University of Illinois at Chicago, USA) for kindly providing the HEK293 cell line and the MRP7 cDNA; Dr. Zhi-Huang Hu in the Department of Medical Oncology, Sun Yat-Sen University Cancer Center for their suggestion and assistance; Zhejiang Beta Pharma Inc for providing the Icotinib hydrochloride tablets. We thank Dr. Mark F. Rosenberg (University of Manchester, Manchester, UK) and Dr. Zsolt Bikádi (Virtua Drug Ltd., Budapest, Hungary) for providing coordinates of ABCG2 homology model.

\section{Funding}

This work was supported by the funds from: 1 . National Institutes of Health (number: 1R15CA143701) and St. John's University Research Seed Grant (number: 579-1110-7002) to Zhe-Sheng Chen; 2. Scholarship Award for Excellent Doctoral Student granted by Ministry of Education (number: 84000-3191003) to De-Shen Wang; 3. De-Shen Wang is a recipient of a fellowship from International Program of 985 Project, Sun Yat-sen University for overseas study at St. John's University. 4. Drs. SS, SVA, RWR and SEB were supported by the Intramural Research Program of the National Institutes of Health, National Cancer Institute, Center for Cancer Research. The funders had no role in study design, data collection and analysis, decision to publish, or preparation of the manuscript.

\section{REFERENCES}

1. Gottesman MM, Fojo T, Bates SE: Multidrug resistance in cancer: Role of ATP-dependent transporters. Nat Rev Cancer 2002;2:48-58.

2. Dean M, Rzhetsky A, Allikmets R: The human ATPbinding cassette $(\mathrm{ABC})$ transporter superfamily. Genome Res 2001;11:1156-1166.

3. Doyle LA, Yang W, Abruzzo LV, Krogmann T, Gao Y,
Rishi AK, Ross DD: A multidrug resistance transporter from human MCF-7 breast cancer cells. Proc Natl Acad Sci U S A 1998;95:15665-15670.

4. Allikmets R, Schriml LM, Hutchinson A, Romano-Spica V, Dean M: A human placenta-specific ATP-binding cassette gene $(\mathrm{ABCP})$ on chromosome $4 \mathrm{q} 22$ that is involved in multidrug resistance. Cancer Res 1998;58:5337-5339.

5. Miyake K, Mickley L, Litman T, Zhan Z, Robey R, Cristensen B, Brangi M, Greenberger L, Dean M, Fojo $\mathrm{T}$, Bates SE: Molecular cloning of cDNAs which are highly overexpressed in mitoxantrone-resistant cells: Demonstration of homology to $\mathrm{ABC}$ transport genes. Cancer Res 1999;59:8-13.

6. Doyle L, Ross DD: Multidrug resistance mediated by the breast cancer resistance protein BCRP (ABCG2). Oncogene 2003;22:7340-7358.

7. Zhou S, Schuetz JD, Bunting KD, Colapietro AM, Sampath J, Morris JJ, Lagutina I, Grosveld GC, Osawa M, Nakauchi $\mathrm{H}$, Sorrentino BP: The ABC transporter Bcrp1/ABCG2 is expressed in a wide variety of stem cells and is a molecular determinant of the side-population phenotype. Nat Med 2001;7:1028-1034.

8. Ho MM, Ng AV, Lam S, Hung JY: Side population in human lung cancer cell lines and tumors is enriched with stem-like cancer cells. Cancer Res 2007;67:4827-4833.

9. Eramo A, Lotti F, Sette G, Pilozzi E, Biffoni M, Di Virgilio A, Conticello C, Ruco L, Peschle C, De Maria R: Identification and expansion of the tumorigenic lung cancer stem cell population. Cell Death Differ 2008;15:504-514.

10. Yoh K, Ishii G, Yokose T, Minegishi Y, Tsuta K, Goto K, Nishiwaki Y, Kodama T, Suga M, Ochiai A: Breast cancer resistance protein impacts clinical outcome in platinumbased chemotherapy for advanced non-small cell lung cancer. Clin Cancer Res 2004;10:1691-1697.

11. Scagliotti GV, Parikh $P$, von Pawel J, Biesma B, Vansteenkiste J, Manegold C, Serwatowski P, Gatzemeier U, Digumarti R, Zukin M, Lee JS, Mellemgaard A, Park K, Patil S, Rolski J, Goksel T, de Marinis F, Simms L, Sugarman KP, Gandara D: Phase III study comparing cisplatin plus gemcitabine with cisplatin plus pemetrexed in chemotherapy-naive patients with advanced-stage nonsmall-cell lung cancer. J Clin Oncol 2008;26:3543-3551.

12. Li L, Sham YY, Bikadi Z, Elmquist WF: PH-Dependent transport of pemetrexed by breast cancer resistance protein. Drug Metab Dispos 2011;39:1478-1485.

13. Assaraf YG: The role of multidrug resistance efflux transporters in antifolate resistance and folate homeostasis. Drug Resist Updat 2006;9:227-246.

14. Gottschling S, Schnabel PA, Herth FJ, Herpel E: Are we missing the target? Cancer stem cells and drug resistance in non-small cell lung cancer. Cancer Genomics Proteomics 2012;9:275-286.

15. Shi Y, Zhang L, Liu X, Zhou C, Zhang L, Zhang S, Wang D, Li Q, Qin S, Hu C, Zhang Y, Chen J, Cheng Y, Feng 
J, Zhang H, Song Y, Wu YL, Xu N, Zhou J, Luo R, Bai C, Jin Y, Liu W, Wei Z, Tan F, Wang Y, Ding L, Dai H, Jiao S, Wang J, Liang L, Zhang W, Sun Y: Icotinib versus gefitinib in previously treated advanced non-small-cell lung cancer (ICOGEN): A randomised, double-blind phase 3 non-inferiority trial. Lancet Oncol 2013;14:953-961.

16. Laurie SA, Goss GD: Role of epidermal growth factor receptor inhibitors in epidermal growth factor receptor wild-type non-small-cell lung cancer. J Clin Oncol 2013;31:1061-1069.

17. Elkind NB, Szentpetery Z, Apati A, Ozvegy-Laczka C, Varady G, Ujhelly O, Szabo K, Homolya L, Varadi A, Buday L, Keri G, Nemet K, Sarkadi B: Multidrug transporter ABCG2 prevents tumor cell death induced by the epidermal growth factor receptor inhibitor Iressa (ZD1839, Gefitinib). Cancer Res 2005;65:1770-1777.

18. Shi Z, Peng XX, Kim IW, Shukla S, Si QS, Robey RW, Bates SE, Shen T, Ashby CJ, Fu LW, Ambudkar SV, Chen ZS: Erlotinib (Tarceva, OSI-774) antagonizes ATP-binding cassette subfamily B member 1 and ATP-binding cassette subfamily G member 2-mediated drug resistance. Cancer Res 2007;67:11012-11020.

19. Yeh KH, Cheng AL, Wan JP, Lin CS, Liu CC: Downregulation of thymidylate synthase expression and its steady-state mRNA by oxaliplatin in colon cancer cells. Anticancer Drugs 2004;15:371-376.

20. Shafran A, Ifergan I, Bram E, Jansen G, Kathmann I, Peters GJ, Robey RW, Bates SE, Assaraf YG: ABCG2 harboring the Gly482 mutation confers high-level resistance to various hydrophilic antifolates. Cancer Res 2005;65:8414-8422.

21 Robey RW, Honjo Y, Morisaki K, Nadjem TA, Runge S, Risbood M, Poruchynsky MS, Bates SE: Mutations at amino-acid 482 in the ABCG2 gene affect substrate and antagonist specificity. Br J Cancer 2003;89:1971-1978.

22. Brabender J, Danenberg KD, Metzger R, Schneider PM, Park J, Salonga D, Holscher AH, Danenberg PV: Epidermal growth factor receptor and HER2-neu mRNA expression in non-small cell lung cancer is correlated with survival. Clin Cancer Res 2001;7:1850-1855.

23. Pirker R, Pereira JR, von Pawel J, Krzakowski M, Ramlau R, Park K, de Marinis F, Eberhardt WE, Paz-Ares L, Storkel S, Schumacher KM, von Heydebreck A, Celik I, O'Byrne KJ: EGFR expression as a predictor of survival for first-line chemotherapy plus cetuximab in patients with advanced non-small-cell lung cancer: Analysis of data from the phase 3 FLEX study. Lancet Oncol 2012;13:33-42.

24. Pick A, Wiese M: Tyrosine kinase inhibitors influence ABCG2 expression in EGFR-positive MDCK BCRP cells via the PI3K/Akt signaling pathway. ChemMedChem 2012;7:650-662.

25. Goler-Baron V, Sladkevich I, Assaraf YG: Inhibition of the PI3K-Akt signaling pathway disrupts ABCG2-rich extracellular vesicles and overcomes multidrug resistance in breast cancer cells. Biochem Pharmacol 2012;83:13401348 .
26. Mogi M, Yang J, Lambert JF, Colvin GA, Shiojima I, Skurk C, Summer R, Fine A, Quesenberry PJ, Walsh K: Akt signaling regulates side population cell phenotype via Bcrp1 translocation. J Biol Chem 2003;278:39068-39075.

27. Shukla S, Chen ZS, Ambudkar SV: Tyrosine kinase inhibitors as modulators of ABC transporter-mediated drug resistance. Drug Resist Updat 2012;15:70-80.

28. Nicolle E, Boumendjel A, Macalou S, Genoux E, AhmedBelkacem A, Carrupt PA, Di Pietro A: QSAR analysis and molecular modeling of ABCG2-specific inhibitors. Adv Drug Deliv Rev 2009;61:34-46.

29. Takezawa K, Okamoto I, Okamoto W, Takeda M, Sakai K, Tsukioka S, Kuwata K, Yamaguchi H, Nishio K, Nakagawa $\mathrm{K}$ : Thymidylate synthase as a determinant of pemetrexed sensitivity in non-small cell lung cancer. Br J Cancer 2011;104:1594-1601.

30. Salnikov AV, Gladkich J, Moldenhauer G, Volm M, Mattern J, Herr I: CD133 is indicative for a resistance phenotype but does not represent a prognostic marker for survival of non-small cell lung cancer patients. Int J Cancer 2010;126:950-958.

31. Bertolini G, Roz L, Perego P, Tortoreto M, Fontanella E, Gatti L, Pratesi G, Fabbri A, Andriani F, Tinelli S, Roz E, Caserini R, Lo VS, Camerini T, Mariani L, Delia D, Calabro E, Pastorino U, Sozzi G: Highly tumorigenic lung cancer CD133+ cells display stem-like features and are spared by cisplatin treatment. Proc Natl Acad Sci U S A 2009;106:16281-16286.

32. Giovannetti E, Lemos C, Tekle C, Smid K, Nannizzi S, Rodriguez JA, Ricciardi S, Danesi R, Giaccone G, Peters GJ: Molecular mechanisms underlying the synergistic interaction of erlotinib, an epidermal growth factor receptor tyrosine kinase inhibitor, with the multitargeted antifolate pemetrexed in non-small-cell lung cancer cells. Mol Pharmacol 2008;73:1290-1300.

33. Chen ZS, Hopper-Borge E, Belinsky MG, Shchaveleva I, Kotova E, Kruh GD: Characterization of the transport properties of human multidrug resistance protein 7 (MRP7, ABCC10). Mol Pharmacol 2003;63:351-358.

34. Robey RW, Honjo Y, van de Laar A, Miyake K, Regis JT, Litman T, Bates SE: A functional assay for detection of the mitoxantrone resistance protein, MXR (ABCG2). Biochim Biophys Acta 2001;1512:171-182.

35. Robey RW, Medina-Perez WY, Nishiyama K, Lahusen T, Miyake K, Litman T, Senderowicz AM, Ross DD, Bates SE: Overexpression of the ATP-binding cassette halftransporter, ABCG2 (Mxr/BCrp/ABCP1), in flavopiridolresistant human breast cancer cells. Clin Cancer Res 2001;7:145-152.

36. Carmichael J, DeGraff WG, Gazdar AF, Minna JD, Mitchell JB: Evaluation of a tetrazolium-based semiautomated colorimetric assay: Assessment of chemosensitivity testing. Cancer Res 1987;47:936-942.

37. Sun YL, Kathawala RJ, Singh S, Zheng K, Talele TT, 
Jiang WQ, Chen ZS: Zafirlukast antagonizes ATP-binding cassette subfamily G member 2-mediated multidrug resistance. Anticancer Drugs 2012;23:865-873.

38. Towbin H, Staehelin T, Gordon J: Electrophoretic transfer of proteins from polyacrylamide gels to nitrocellulose sheets: Procedure and some applications. Proc Natl Acad Sci U S A 1979;76:4350-4354.

39. Sun YL, Chen JJ, Kumar P, Chen K, Sodani K, Patel A, Chen YL, Chen SD, Jiang WQ, Chen ZS: Reversal of MRP7 (ABCC10)-mediated multidrug resistance by tariquidar. PLoS One 2013;8:e55576.

40. Shukla S, Robey RW, Bates SE, Ambudkar SV: The calcium channel blockers, 1,4-dihydropyridines, are substrates of the multidrug resistance-linked $\mathrm{ABC}$ drug transporter, ABCG2. Biochemistry-Us 2006;45:8940-8951.

41. Tiwari AK, Sodani K, Dai CL, Abuznait AH, Singh S, Xiao ZJ, Patel A, Talele TT, Fu L, Kaddoumi A, Gallo JM, Chen ZS: Nilotinib potentiates anticancer drug sensitivity in murine ABCB1-, ABCG2-, and ABCC10-multidrug resistance xenograft models. Cancer Lett 2013;328:307317.

42. Sodani K, Patel A, Anreddy N, Singh S, Yang DH, Kathawala RJ, Kumar P, Talele TT, Chen ZS: Telatinib reverses chemotherapeutic multidrug resistance mediated by ABCG2 efflux transporter in vitro and in vivo. Biochem Pharmacol 2014 